\begin{tabular}{lc}
\hline & ANNALES \\
& UNIVERSITATIS MARIAE CURIE-SKŁODOWSKA \\
LOL. V & SECTIO N \\
\hline
\end{tabular}

ISSN: 2451-0491 • e-ISSN: 2543-9340 • CC-BY 4.0 • DOI: 10.17951/en.2020.5.239-250

\title{
Jasna, promienna i optymistyczna - o wartościach opowiadań Zofii Żurakowskiej
}

\section{Fair, Bright, Optimistic - about Literary Work of Zofia Żurakowska}

\author{
Elżbieta Kruszyńska \\ Uniwersytet Mikołaja Kopernika w Toruniu. Wydział Humanistyczny \\ Fosa Staromiejska 3, 87-100 Toruń \\ amela@umk.pl \\ https://orcid.org/0000-0003-4028-3378
}

\begin{abstract}
The article describes selected short stories of Zofia Żurakowska in the aspect of virtues which are present in them. Although the writer's private life was rather stormy she could maintain optimistic attitude and faith in human being, what is reflected in her literary work dedicated for children and youth. She was undertaking in her short stories important social and moral issues. The most important values present in her literary work are: freedom, independence, tolerance, kindness, love. The writer was putting her characters in the complicated, dramatic situations, minding that they always were able to act in the name of good. Uniqueness of Żurakowska's literature consists in the fact that she was a groundbreaker introducing detective and criminal plots. Despite the changing world the virtues present in Żurakowska's literature remain fresh and valid up-to-date. The language of her books has also not lost its relevance - it is clear, understandable and easy.
\end{abstract}

Keywords: Zofia Żurakowska; short stories; children and youth; important social and moral issues 


\begin{abstract}
Abstrakt. W artykule zaprezentowano wybrane opowiadania Zofii Żurakowskiej pod kątem obecnych w nich wartości. Pisarka, mimo że nie miała łatwego życia prywatnego, zachowała optymizm i wiarę w człowieka, czego odzwierciedleniem jest jej twórczość dla dzieci i młodzieży. W opowiadaniach podejmowała ważne tematy społeczne i obyczajowe, była wrażliwa na krzywdę ludzką. Jej pisarstwu przyświecały takie wartości, jak: wolność, bezinteresowność, tolerancja, życzliwość i miłość. Pisarka kreowała bohaterów głęboko przeżywających swoje dramaty i niepokoje, ale zawsze działających w imię dobra. Oryginalność literatury tworzonej przez Żurakowską polega też na tym, iż jako jedna z pierwszych wprowadziła do swych utworów wątki detektywistyczne i kryminalne. Pomimo tego, że zmieniły się realia, stosunki społeczne, wizerunek szkoły i relacje między młodzieżą a dorosłymi, to na pewno nie uległy zmianie problemy, postawy ludzkie i wartości prezentowane przez pisarkę. Nie stracił na aktualności również język jej książek, ponieważ jest komunikatywny, czytelny i prosty.
\end{abstract}

Słowa kluczowe: Zofia Żurakowska; opowiadania; dzieci i młodzież; ważne tematy społeczne i obyczajowe

Żywioł epicki wraz z „niezauważalnym stylem”, prostym, jasnym i dokładnym oraz stałym dążeniem do pogłębienia psychologicznej motywacji losów bohatera upoważniał już współczesnych Żurakowskiej krytyków do wysunięcia jej prozy na czołowe miejsce w obrębie powojennej literatury dla dzieci i młodzieży. (Białek 1979: 121)

[...] osiągnęła taką doskonałość, że jej opowiadania nie utraciły nic do dzisiaj ze swojej świeżości, ze swojej bezpośredniości i ze swojego palpitującego wzruszenia. (cyt. za: Białek 1994: 163)

\title{
WPROWADZENIE
}

Jedną z najbardziej zapomnianych i jednocześnie niedocenionych pisarek dla dzieci i młodzieży okresu dwudziestolecia międzywojennego jest Zofia Żurakowska ${ }^{1}$. Jej twórczością zajmowało się niewielu krytyków, m.in. Kazimierz Czachowski, Krystyna Kuliczkowska, Jerzy Ficowski, ale jej książki recenzowali ludzie o znaczących nazwiskach: Maria Dąbrowska, Hanna Mortkowicz-Olczakowa,

1 Teza ta odnosi się w części do obecnego zainteresowania książkami Żurakowskiej przez młodych czytelników. Należy zauważyć, że w latach 1945-1948 polskie dzieci zaczytywały się jej utworami. Ponownie pamięć tym dziełom przywróciły wydawnictwa w latach 80. i 90., ich popularność wśród czytelników jednak nie wzrosła. 
Antoni Słonimski, Anna Kamieńska, Jarosław Iwaszkiewicz, Leon Piwiński. Wszystkie oceny były bardzo wysokie. W okresie międzywojennym książki Żurakowskiej zostały wpisane przez Komisję Oceny Książek z Zakresu Literatury Pięknej na listę zalecanych dla młodzieży szkolnej lektur dzieł współczesnych wybitnych polskich pisarzy, obok takich autorów jak Helena Boguszewska, Maria Dąbrowska, Halina Górska, Janusz Korczak czy Ewa Szelburg-Zarembina (zob. Spis Książek Poleconych... 1929). Współcześni badacze również zajmują się analizą twórczości Żurakowskiej, głównie pod kątem obecności jej książek na rynku wydawniczym, w kanonach lektur szkolnych czy też czytelnictwa dzieci i młodzieży (zob. m.in. Graban-Pomirska 2016: 87-93; Gwadera 2009: 167-176; Nadolna 2009: 109-128; Nadolna 2013: 30-37; Pytlos 2013: 106-132).

Żurakowska została wychowana $\mathrm{w}$ atmosferze wysokiej kultury, patriotyzmu i miłości do bliźniego: „Była jedną z czterech córek szczęśliwej rodziny, chowanych w dostatku i miłości, pod czułą opieką rodziców" (Mortkowicz-Olczakowa 1959: 273). W młodości przeżyła śmierć czternastoletniej siostry Felicji i ojca, co miało duży wpływ na stan emocjonalny przyszłej pisarki. Ale i później w jej życiu działo się wiele niedobrego: tragiczna śmierć męża w pół roku po ślubie oraz utrata majątku, bardzo wyczerpująca praca pielęgniarska i śmiertelna choroba. Prawdopodobnie twórczość pisarska dla dzieci i młodzieży była swoistą rekompensatą w jej życiu osobistym, pozbawionym domu i ciepła rodzinnego. Zofia Adamczykowa (red. 1981:31) tak pisała o jej utworach: „I rzecz zdumiewająca - nie ma w nich cienia smutku. Tchną pogodą, optymistyczną wiarą w człowieka i w sens ludzkich działań, dowodząc zarazem siły i hartu ducha pisarki". Wydawać by się mogło, że twórczość literacka stała się prawdziwym remedium na cierpienie psychiczne i fizyczne Żurakowskiej. Dokonany przez nią wybór adresata tak motywuje Jerzy Ficowski: „Pisząc dla dzieci, pisała do siebie dawnej; pisząc dla dorosłych, musiałaby pisać do siebie obecnej, a wtedy koszmar snu i jawy nie dałby się już odepchnąć ani ominąć" (cyt. za: Ziółkowska-Sobecka 1989: 39). Była to ucieczka pisarki do kraju szczęśliwego dzieciństwa. Zofia Żurakowska debiutowała na łamach czasopism dziecięcych („W słońcu”, „Płomyk”) tzw. małymi formami prozatorskimi; tu także ukazywały się jej pogadanki dydaktyczno-literackie. Choć dorobek literacki autorki nie jest obszerny ${ }^{2}$, to większość jej utworów znalazła się na liście lektur szkolnych, w wypisach szkolnych oraz na liście książek polecanych do bibliotek szkolnych

2 Spuścizna literacka Żurakowskiej obejmuje: dylogię Skarby (1925) i Pożegnanie domu (1927), zbiór opowiadań Trzy srebrne ptaki (1927), opowiadanie Pójdziemy w świat (1928), powieści Roman i dziewiętnastu oraz Fetysz (1930), opowiadania wydane pośmiertnie Jutro niedziela i Chtopcy na strychu (1935). Ponadto jedno opowiadanie dla dorosłych - Buty (1928). 
i nauczycielskich. Talent Żurakowskiej objawił się spontanicznie i trwał zbyt krótko. Zdołała napisać zaledwie kilka utworów dla młodzieży. „W tych książkach zawarł się cały heroizm pięknej i zwycięskiej postawy moralnej wobec krzywdzącego losu" (Mortkowicz-Olczakowa 1959: 275).

Różnorodna twórczość Zofii Żurakowskiej związana jest z przemianami oraz cechami charakterystycznymi dla prozy dwudziestolecia międzywojennego. Najbardziej znaczące przeobrażenia w pisarstwie tego okresu można zaobserwować na przykładzie prozy obyczajowej. Literatura tendencyjna moralizatorska zastępowana była przez utwory awangardowe, realistyczne, psychologiczne, pogłębiające ujęcie człowieka i świata. Zwłaszcza w literaturze dla dzieci i młodzieży owe przemiany komplikowały się, ponieważ do tej pory była ona podporządkowana przede wszystkim funkcji dydaktycznej ${ }^{3}$. W literaturze dla dzieci i młodzieży dwudziestolecia międzywojennego wyodrębnia się dwa główne nurty: prozę moralistyczną (dominującą w latach 20.) i prozę populistyczną (lata 30.). Z pierwszym nurtem związane są utwory o akcentach społecznych, patriotycznych, moralnych, psychologicznych, a z drugim umownie wiąże się prozę realistyczną (pozostawała ona pod wpływem doświadczeń grupy „Przedmieście”, a także postępowych twórców lat 30.).

Problematyka utworów Żurakowskiej odwołuje się do doświadczeń jej pokolenia, nosi cechy autobiografizmu i stylu realistycznego. W utworach pisarki można znaleźć motywy patriotyczne, problematykę życia powojennego, przemiany obyczajowe, społeczne i moralne. Autorka poruszała także problemy życia rodzinnego, przedstawiała dramaty i rozterki życiowe młodych bohaterów oraz grup młodzieżowych. Żurakowska, wspólnie z Korczakiem i Dąbrowską, przyczyniła się do uatrakcyjnienia i unowocześnienia literatury dla dzieci i młodzieży, uwolnienia jej od skostniałych schematów, a dzięki zdolności widzenia świata w szerszej perspektywie i sprawnego formułowania uogólnień stworzyła literaturę skłaniającą do głębszych refleksji nad życiem.

\section{WĘDRÓWKA, PRZYGODA I PATRIOTYZM}

Posiadanie domu, utrata domu, szukanie domu, powrót do domu - to motywy będące częstymi składnikami fabularnymi utworów Zofii Żurakowskiej. Ale poza domem także istnieje życie, inni ludzie, interesujący świat - żeby go zaprezentować, pisarka sięgała po znane w literaturze motywy podróży czy wędrówki. Na motywie

3 W przeobrażeniach i zmianach literatury dla dzieci i młodzieży decydującą rolę odegrali m.in. Janusz Korczak, Maria Dąbrowska, Zofia Żurakowska, Helena Bobińska, Fryderyka Lazarusówna, Benedykt Hertz, Kazimierz Rosinkiewicz. 
wędrówki oparte jest opowiadanie Pójdziemy w świat. Wakacyjna włóczęga ojca z córką pozwala poznać życie mieszkańców niepodległej Polski, zachwycać się pięknem ojczystej przyrody, radzić sobie z różnymi życiowymi niedogodnościami. Jednocześnie uaktywnia ona tęsknotę za domem (zwłaszcza u Henrysi) oraz docenienie jego wartości i znaczenia. Opowiadanie Żurakowskiej Pójdziemy w świat wpisuje się w wyróżniony przez Janinę Abramowską (1978: 125) schemat dobrowolnej wędrówki w świat, by poznać własny kraj lub bez tego celu. Zofia Budrewicz (2013: 217) zauważyła, że pisarka z wielkim talentem pedagogicznym prezentowała motyw drogi, wędrówki, prowadzący bohaterów (ale także odbiorców) do „odkrywania bliskości świata przez ujawnianie się jego poprzedniej obcości”. Natomiast Józef Z. Białek (1994: 155) stwierdził, że Żurakowska stworzyła „swego rodzaju »pieśń o ziemi naszej«, sławiąc urodę kraju, który odzyskał niepodległość, kreśląc stosunki między ludźmi oparte na szczerości, przyjaźni i braterstwie".

Taką, wydawałoby się niezaplanowaną i pozbawioną z pozoru głębszego celu poznawczego, wędrówkę wiodą Henrysia wraz z ojcem. Na swej drodze spotykają się z niezwykłą serdecznością i gościnnością nowo poznanych ludzi (w chłopskiej chacie, na plebanii, w szlacheckim dworze), którzy najpierw zupełnie obcy i nieznani dziewczynce, z czasem stają się ludźmi swojskimi. Znamienne są słowa Henrysi wypowiedziane po powrocie do domu z wakacyjnej wędrówki z ojcem: „Bo czy wie Bronisława, o czym przekonaliśmy się w drodze? Że prawie wszyscy ludzie są sobie braćmi, a nawet także i zwierzęta, i wszystko takie jest przyjacielskie" (Żurakowska 1972: 139-140). Można przypuszczać, że w słowach tych zawarta jest postawa ideowa pisarki. W tym samym opowiadaniu dostrzegamy również popularną u Żurakowskiej ideę przyjaźni przekraczającej bariery społeczne (między Henrysią, pochodzącą ze sfery mieszczańskiej, i Stefką - chłopskiego pochodzenia), a także głęboką wiarę w człowieka, w jego dobroć, która - niczym w baśniach - zawsze pokona i zwycięży zło. Według pisarki dobroć jest bronią posiadającą wielką moc pojednania. W związku z tym swych bohaterów celowo stawiała w takich sytuacjach, które zmuszały ich do dokonywania wyborów i przezwyciężania negatywnych skłonności. Prezentując pozytywne postawy bohaterów, autorka realizuje aktualny wówczas cel wychowawczy sformułowany przez Aleksandra Świętochowskiego w następujący sposób: „Niczego Polska nie potrzebuje bardziej dla swej szczęśliwej przyszłości niż czystych i mocnych charakterów" (cyt. za: Adamczykowa red. 1981: 34).

Zdobyte w ciągu swobodnej kilkutygodniowej włóczęgi doświadczenia przyniosły Henrysi cenne informacje o ludziach, o sobie i o ojcu („posiadanie go nie jest prawem wiecznym, a tylko szczęściem wyjątkowym" [Żurakowska 1957: 134]), a także - dzięki jego talentowi pedagogicznemu - o bezdomności, tułaczce i wojnie: 
Tak jest na wojnie, Henrysiu - tylko stokroć gorzej. Bo ty przez chwilę tylko niepokoiłaś się i cierpiałaś głód i zmęczenie, a na wojnie żołnierze i wygnańcza ludność ze wsi i miast zbombardowanych, lata całe znosić to muszą. Ale szlak wielkiej wojennej parady, znaczony jest lasem krzyżów, nie tylko na piersiach, ale i na mogiłach. (tamże)

[...] jedna tylko sprawa na świecie warta jest wojny, to wolność. Ale to jedyna rzecz godna krwi i łez człowieczych" (tamże: 126).

Motyw wędrówki czytelnik może znaleźć jeszcze w opowiadaniu Fetysz, w którym para głównych bohaterów - Gabrysia i Hubert - właściwie cały czas jest w drodze w poszukiwaniu kamiennego przycisku do papieru, na którym ojciec dziewczynki wyrył niezwykle ważną dla dalszych badań naukowych formułę związaną z wynalazkiem z dziedziny chemii. Oczywiście wędrówka młodych ludzi obfituje w liczne przygody, ale ma też dla odbiorcy walor poznawczy i edukacyjny. Pisarka w każdym swoim utworze starała się przemycać ważne prawdy o świecie, pokazywać młodemu czytelnikowi, jakimi wartościami powinien się kierować w życiu.

Wśród tej ostatniej nędzy ścian i sprzętów połyskiwały niechętne oczy w twarzach czarnych i wychudłych, a ręce żółte i drapieżne otwierały z trzaskiem drzwi i okna, by wyjrzeć na to nie widywane w tym przeklętym miejscu zjawisko - wypasionego konia i dobrze ubranych ludzi. [...] wstyd ich ogarnął na myśl, że trzeba będzie stanąć przed oczami ludzi tak bardzo pokrzywdzonych i przypomnieć im, że bywa na świecie los lepszy od ich nieznośnego losu. Bezradna rozpacz ogarnęła ich dusze, a serca zapłonęły żądzą, by coś się przecież na tym świecie odmieniło i wszystkim dane było prawo do szczęścia i wesołości. (tamże: 204)

Ten jakże wymowny fragment pokazuje, że Żurakowska żywo reagowała na krzywdę społeczną i starała się uwrażliwić na nią także najmłodsze pokolenie. W związku z tym, podobnie jak twórcy literatury osiemnastowiecznej, wykorzystywała motyw wędrówki do przekazywania odbiorcy treści dydaktycznych, pokazując, jak przeżycia i przygody podróżników wzbogacają ich o nowe doświadczenia życiowe i wpływają na zmianę ich myślenia i spojrzenie na otaczającą rzeczywistość.

Akcja opowiadań Żurakowskiej toczy się wokół spraw codziennych i jest utrzymana w konwencji realistycznej. Bieg zdarzeń jest wartki, akcja żywa, obrazowanie sugestywne, a kreacja bohaterów - plastyczna. Obok tych niewątpliwych zalet utwory te cechuje ponadto przygoda i fantazja. W opowiadaniu Pójdziemy w świat w scenie przedstawiającej spacer Henrysi z panną Zosią po dworskim ogrodzie 
główna bohaterka przeżywa przygodę z pogranicza rzeczywistości i fantazji, snu i jawy. Dzieje się tak za sprawą opowieści o tajemniczej damie z portretu, natomiast w Fetyszu główni bohaterowie przeżywają liczne, niezwykle zawiłe perypetie związane z poszukiwaniem kamiennego przycisku. Z kolei w opowiadaniu Jutro niedziela fabuła wzbogacona jest o wątki detektywistyczne. I choć intryga opiera się na śledzeniu, tropieniu i poszukiwaniu przestępcy, w istocie okazuje się, że nie jest on przestępcą, a detektywowi zupełnie nie zależy na tym, aby go ujawnić. $Z$ wątkiem sensacyjno-kryminalnym mamy też do czynienia w opowiadaniu Chłopcy na strychu. Trzej bracia: Michał, Jaś i Luś, choć na co dzień musieli głównie dbać o to, by mieć co jeść, w co się ubrać oraz pilnować tego, by odrobić lekcje, ale też posprzątać swój prowizoryczny dom, nie przestali przecież być dziećmi. Chłopców cechuje więc nieskrępowana chęć zabawy, beztroski i przeżywania ciekawych przygód. Taka właśnie przygoda przytrafiła im się, gdy wiedzeni dziecięcą ciekawością świata chcieli obejrzeć z bliska basen i niezwykłe zabawki znajdujące się w pobliskim zamku. Zbieg okoliczności sprawia, że w trakcie swej nocnej eskapady trafiają na złodziei. I choć w opowiadaniu następują chwile bardzo niebezpieczne, to wszystko kończy się dla chłopców pomyślnie. Żurakowska tym samym przekonuje czytelnika, że wszędzie i zawsze można spotkać na swej drodze dobrych ludzi, którzy nas wesprą i nam pomogą, a zwłaszcza tym, którzy rzeczywiście tej pomocy i opieki potrzebują.

Zwięzłość, spójność kompozycji, emocjonująca fabuła wolna od taniej sensacji, a do tego spora dawka humoru - to bezsprzeczne walory opowiadań Zofii Żurakowskiej. Są one jednocześnie konkretyzacją artystycznego światopoglądu pisarki i wyrazem jej wiary w swobodę, niczym nieskrępowaną wolność, bezinteresowność, tolerancję, życzliwość i miłość.

Niezwykle istotnym walorem opowiadania Pójdziemy w świat jest ponadto lekcja szeroko pojętego patriotyzmu, której pisarka udziela młodzieży. Oczami narratora i bohaterów zachwyca się polskim krajobrazem, ziemią i ludźmi, a wszystko, co ojczyste, w wyraźny sposób idealizuje. Ma więc to charakter - jak stwierdził Białek (1979) - swoistej „pieśni o ziemi naszej”, wysławiającej urodę kraju, który odzyskał niepodległość. Relacje między ludźmi są tu oparte na przyjaźni i szczerości. Mimo że w opowiadaniu nie ma cech pozwalających na identyfikację trasy wycieczki, czyli brakuje elementów, które składałyby się na warstwę poznawczą utworu, to zabieg ten ułatwia koncentrację na wartościach uniwersalnych. Jak słusznie zauważyła Zofia Budrewicz:

[...] literatura dziecięca z motywami wędrówek kierowała uwagę na doświadczanie polskiej ziemi jako swojskości rodzinnej i zarazem rodzimej. [...] Narrator w każdym niemal z obrazków podkreśla, że istotą zadomowienia w swojskości 
jest troska o bezpieczeństwo jego mieszkańców, szacunek wobec miejsca, opieka itp. Są to „wyznaczniki” postawy odpowiedzialnego korzystania z wolności w przestrzeni, opartej na harmonijnym współistnieniu. (Budrewicz 2013: 219)

Zgodnie z tymi zasadami tworzyła swoje opowiadania Zofia Żurakowska, zwłaszcza te, w których prezentowała tematykę patriotyczną i krajoznawczą. Jej proza w afirmatywny sposób ukazuje rzeczywistość odradzającego się kraju, przemiany społeczne, kulturalne i cywilizacyjne; kształtuje też apologetyczny stosunek młodego pokolenia do wszystkiego, co polskie, a pokazując rodzime krajobrazy i wykorzystując uniwersalny topos „ziemi ojczystej”, wpływa na budowanie tożsamości narodowej młodzieży (zob. Kolbuszewski 1994; Petrykowski 2003; Rypel 2012; Stępniak 1984).

\section{DOM I SIEROTY}

Półsieroty to niemal znak rozpoznawczy bohaterów Zofii Żurakowskiej. Zważywszy na to, że rodzic, który się nimi samodzielnie opiekuje, jest zwykle bardzo zajęty zarabianiem pieniędzy na utrzymanie rodziny, należy podkreślić, że dzieci wychowują się prawie jak sieroty (por. Jonca 1994). Tak jest w przypadku braci Michała, Jasia i Lusia z opowiadania Chtopcy na strychu oraz Gabrysi z utworu Fetysz. Ojciec chłopców był zmuszony wyjechać za granicę, żeby zarobić na przysłowiowy kawałek chleba, a ojciec bohaterki Fetysza jest nieustannie zajęty pracą naukową. Wszystkim dzieciom bardzo doskwiera brak matek. Taka sytuacja wymusza na nich przyspieszony proces dojrzewania, samodzielne zdobywanie doświadczeń, podejmowanie decyzji, sprawdzanie się w trudnych sytuacjach, odpowiedzialność za siebie i za innych. Bohaterowie Żurakowskiej potrafią oceniać własne postępowanie, dyskutować z rówieśnikami i rozstrzygać skomplikowane problemy życiowe. Zdolni są do zajmowania określonego stanowiska wobec trudnych dylematów moralnych i uczuciowych. To właśnie sprawia, że postacie z jej opowiadań są kreowane z dużym prawdopodobieństwem psychologicznym. Białek zaliczył twórczość Żurakowskiej do tzw. „kierunku »psychologizującego«, zmierzającego pod wpływem pedagogiki naturalistycznej i psychoanalizy do ukazania wewnętrznego świata dziecka oraz do kształtowania jego postaw moralnych i społecznych" (cyt. za: Adamczykowa red. 1981: 36).

Młodzi bohaterowie wchodzą w dorosłe życie, w dorosłe problemy, mając po kilkanaście lat. Gabi zgrabnie przejmuje obowiązki gospodyni domu, dba o ogród, robi przetwory, hoduje zwierzęta, na co dzień boryka się z kłopotami, z jakimi mają do czynienia zazwyczaj dorośli - mimo to stara się radzić sobie sama, nie obarcza nimi zapracowanego i nieobecnego ojca. Jest przy tym 
niezwykle empatyczna - wie, że ojcu trudno żyć bez ukochanej żony, zarabiać samodzielnie na ich utrzymanie, dlatego postanawia nie dostarczać mu własnych trosk i nie mówi nigdy o żadnych kłopotach czy smutkach, chociaż ich jej nie brakuje. Dziewczyna jest bardzo dzielna i zaradna, a ponadto pracowita, uczynna, dobra i wrażliwa. Żurakowska zastosowała w Fetyszu często stosowany przez pisarzy dwudziestolecia międzywojennego (a zwłaszcza przez autorów powieści dla dziewcząt) chwyt polegający na skontrastowaniu pozytywnej i negatywnej bohaterki. Przeciwieństwem Gabrysi jest Marylka - typ salonowej lalki, która stroni od wszelkiego wysiłku fizycznego, gardzi pracą. Jest pusta i próżna (zależy jej tylko na tym, by pięknie wyglądać), a przy tym to obłudna, zawistna i złośliwa intrygantka. Taka opozycja ma za zadanie uwypuklić pozytywne cechy głównej bohaterki i wyraźnie pokazać, po której stronie stoi autorka.

Żurakowską interesowały przeżycia i konflikty dzieci, ich relacje z rówieśnikami i z dorosłymi. W przypadku tych drugich jeśli dochodzi do konfliktu, to zazwyczaj wyrasta on na podłożu rywalizacji o ich względy (tak jest w opowiadaniu Jutro niedziela). Często za sprawą zbyt zajętych (ojcowie Zosi, Gabi i trzech braci ze strychu) czy nazbyt „dziecinnych”, nieodpowiedzialnych dorosłych (ojciec Henrysi), dzieci się usamodzielniają. Mimo to nie ma między dorosłymi i dziećmi żadnej bariery, istnieje raczej partnerstwo. Zarówno jednym, jak i drugim Żurakowska przyznaje prawo do błędu, traktuje ich serio i z szacunkiem. Przyjaźń i rodzina są dla pisarki wartościami nadrzędnymi, przywracają bohaterom radość życia i wewnętrzną siłę, mimo tego, iż są niepełne. Bracia podejmują wprost heroiczną walkę o przetrwanie - wolą mieszkać bez opieki dorosłej, obcej osoby, ze strony której nie odczuwają żadnych pozytywnych, ciepłych uczuć; wolą sami troszczyć się o siebie nawzajem, nawet za cenę niedojadania czy mieszkania w spartańskich warunkach. Chłopcy są niezwykle dzielni, zaradni i dojrzali ponad swój wiek. Z ogromną pieczołowitością i oddaniem tworzą sobie prowizoryczny dom. Udaje im się to dzięki sprytowi i pomysłowości, ale przede wszystkim dzięki uczuciu, jakie ich łączy. To wzajemna miłość i dbałość o siebie spajają tę prowizoryczną rodzinę, pozwalając im przetrwać czas bez ojca, by w końcu doczekać się poprawy losu.

Typem dziecka półsieroty jest również Henrysia z opowiadania Pójdziemy ws świat. Wychowywana jest przez ojca, człowieka dość szalonego, według którego „można czasem iść za podszeptem fantazji i robić to, co znienacka przychodzi do głowy, o ile pomysł ten dla nikogo nie jest przykry ani szkodliwy" (Żurakowska 1972: 78). Henrysia jest dzieckiem pogodnym, choć także rozważnym i dojrzałym jak na swój wiek. W czasie wakacyjnej wędrówki stara się rozsądnie podchodzić do wielu spraw, ale też czerpie jak najwięcej radości z obcowania z naturą, chętnie nawiązuje nowe przyjaźnie. Postępuje zgodnie z zasadą ojca: 
Dziś, Henrysiu, dziś właśnie musisz być jak najlepsza, jak najmądrzejsza i jak najweselsza - nie licz na dzień jutrzejszy, moja córko. Dziś oddaj ludziom, co masz im do oddania, i bierz, co możesz wziąć, i kochaj, co masz zamiar kochać, i rób, co masz do zrobienia. (tamże: 78-79)

\section{ZAKOŃCZENIE}

Żurakowska w sposób interesujący i oryginalny przedstawiała dziecko w obliczu skomplikowanej rzeczywistości. Wszystkie stworzone przez nią postacie są „prawdziwe”, bardzo przekonujące dla młodego odbiorcy. Najczęściej są to bohaterowie dynamiczni, obdarzeni różnymi temperamentami, ale nie wyidealizowani. Poznajemy ich w zróżnicowanych środowiskach i sytuacjach, widzimy bogaty świat przeżyć młodych ludzi. Autorka zaś - doskonała znawczyni dziecięcej psychiki - wymaga od nich nie tylko umiejętności oceny wydarzeń, z którymi się stykają, lecz także skłonności do wzruszeń i refleksji.

W epoce dwudziestolecia pisarkę można by uznać za prekursorkę ukazywania literackiego modelu dziecko - rzeczywistość, zauważonego w omówionych utworach. Mimo wielu ciemnych stron życia jej twórczość jest jasna, promienna i optymistyczna. Spełnia swoistą funkcję terapeutyczną, choć nie przemilcza spraw trudnych, drażliwych. Jej bohaterowie głęboko przeżywają swoje dramaty i niepokoje, ale zawsze działają w imię ludzkich celów. Proza obyczajowo-psychologiczna Żurakowskiej odegrała istotną rolę w rozwoju literatury dla dzieci i młodzieży. W epoce dwudziestolecia międzywojennego podobne postacie kreowali w swych utworach m.in. Halina Górska, Helena Boguszewska, Fryderyka Lazarusówna, Kazimierz Rosinkiewicz.

Oryginalność literatury tworzonej przez Żurakowską polega też na tym, że jako jedna z pierwszych wprowadziła do swych utworów wątki detektywistyczne, przygodowe. W późniejszej literaturze widoczne jest to przede wszystkim u takich pisarzy, jak: Adam Bahdaj, Zbigniew Nienacki, Edmund Niziurski. W ich powieściach obok żywej akcji, obfitującej w nagłe spięcia dramatyczne, znajdziemy pogłębione psychologicznie sylwetki bohaterów oraz walory pedagogiczne podobne do tych, jakie prezentowała autorka Fetysza.

Opowiadania Żurakowskiej ze względu na wartości w nich promowane przez pisarkę mogą być wciąż aktualne i czytane przez współczesne dzieci i młodzież. Pisarka z wielkim wyczuciem przedstawiła problemy społeczne, była niezwykle wrażliwa na krzywdę ludzi, a zwłaszcza dzieci. Podpowiadała, jak można rozwiązać wiele niepomyślnych sytuacji, zawsze stawała po stronie dobra, sprawiedliwości i prawdy, dlatego jej bohaterowie są tacy autentyczni i mogą stać się - mimo zmieniających się realiów - wzorami do naśladowania dla kolejnych pokoleń czytelników. 


\section{BIBLIOGRAFIA}

Abramowska, J. (1978). Peregrynacja. W: M. Głowiński, A. Okopień-Sławińska (red.), Przestrzeń i literatura. Studia (s. 125-158). Wrocław: Zakład Narodowy im. Ossolińskich, Wydawnictwo PAN.

Adamczykowa, Z. (red.). (1981). Szkice z literatury dla dzieci i młodzieży. Katowice: Uniwersytet Śląski.

Białek, J.Z. (1979). Literatura dla dzieci i młodzieży w latach 1918-1939. Warszawa: WSiP.

Białek, J.Z. (1994). Przymierze z życiem. Proza Zofii Żurakowskiej. W: tegoż, Przymierze z dzieckiem. Studia i szkice o literaturze dla dzieci (s. 139-163). Kraków: Wydawnictwo BUS.

Budrewicz, Z. (2013). Lekcje polskiego krajobrazu. Międzywojenna proza podróżnicza dla młodzieży. Kraków: Wydawnictwo Naukowe Uniwersytetu Pedagogicznego.

Graban-Pomirska, M. (2016). Zofia Żurakowska - ukryta melancholia. Bibliotekarz Podlaski, nr 2, 87-96.

Gwadera, M. (2009). Współczesny rynek książki dla dzieci i młodzieży. W: K. Heska-Kwaśniewicz (red.), Literatura dla dzieci i młodzieży (po roku 1980) (T. 2; s. 167176). Katowice: Wydawnictwo Uniwersytetu Śląskiego.

Jonca, M. (1994). Sierota w literaturze polskiej dla dzieci w XIX wieku. Wrocław: Wydawnictwo Uniwersytetu Wrocławskiego.

Kolbuszewski, J. (1994). Od Pigalle po Kresy. Wrocław: Wydawnictwo Uniwersytetu Wrocławskiego.

Mortkowicz-Olczakowa, H. (1959). Bunt wspomnień. Warszawa: PIW.

Nadolna, M. (2009). Powrót książek zakazanych dla młodego odbiorcy po transformacji ustrojowej w latach dziewięćdziesiątych. W: K. Heska-Kwaśniewicz (red.), Literatura dla dzieci i młodzieży (po roku 1980) (T. 2; s. 109-128). Katowice: Wydawnictwo Uniwersytetu Śląskiego.

Nadolna, M. (2013). Próby przywrócenia pisarzy dwudziestolecia przez prywatnych wydawców w drugiej połowie lat 40. W: K. Heska-Kwaśniewicz, K. Tałuć (red.), Literatura dla dzieci i mtodzieży (1945-1989) (T. 3; s. 30-37). Katowice: Wydawnictwo Uniwersytetu Śląskiego.

Petrykowski, P. (2003). Edukacja regionalna. Problemy podstawowe i otwarte. Toruń: Uniwersytet Mikołaja Kopernika.

Pytlos, B. (2013). Powieść dla dziewcząt w latach 1945-1968. Co powinny czytać dziewczęta? W: K. Heska-Kwaśniewicz, K. Tałuć (red.), Literatura dla dzieci i młodzieży (1945-1989) (T. 3; s. 106-132). Katowice: Wydawnictwo Uniwersytetu Śląskiego.

Rypel, A. (2012). Ideologiczny wymiar dyskursu edukacyjnego na przykładzie podręczników języka polskiego z lat 1918-2010. Bydgoszcz: Wydawnictwo Uniwersytetu Kazimierza Wielkiego.

Spis Książek Poleconych do bibliotek szkolnych przez Komisję Oceny Ksiażek do czytania dla młodzieży szkolnej przy Ministerstwie Wyznań Religijnych i Oświecenia Publicznego w latach 1923 do 1928 wtacznie. (1929). Warszawa. 
Pobrane z czasopisma Annales N - Educatio Nova http://educatio.annales.umcs.pl Data: 26/04/2023 10:09:44

Stępniak, K. (1984). Z zagadnień poetyki krajobrazu w literaturze polskiej połowy wieku XIX. W: L. Ludorowski (red.), Z problemów poetyki historycznej (s. 19-31). Lublin: UMCS.

Ziółkowska-Sobecka, M. (1989). Lektury Kolumbów. Rozważania o prozie dla młodzieży dwudziestolecia międzywojennego. Warszawa: Nasza Księgarnia.

Żurakowska, Z. (1957). Jutro niedziela, Chtopcy na strychu, Pójdziemy w świat, Fetysz. Warszawa: Nasza Księgarnia.

Żurakowska, Z. (1972). Jutro niedziela i inne opowiadania. Warszawa: Nasza Księgarnia. 